\title{
Brain Tissue Oxygen Monitoring and the Intersection of Brain and Lung: A Comprehensive Review
}

\author{
Laura B Ngwenya MD PhD, John F Burke MD PhD, and Geoffrey T Manley MD PhD
}

\author{
Introduction \\ Why Monitor Brain Tissue Oxygen After Injury? \\ How Should Brain Tissue Oxygen Be Measured? \\ The Technology of the Partial Pressure of Brain Oxygen \\ Validation of Cerebral Oxygen Monitoring \\ Hyperventilation and Carbon Dioxide Reactivity \\ Brain Tissue Oxygen and Cerebral Pressure Autoregulation \\ Cerebral Oxygen Reactivity \\ Brain Tissue Oxygen and Oxygen Diffusion \\ Brain Tissue Oxygenation and the Role of the Lung \\ Lung-Protective Strategies and Brain Tissue Oxygen \\ Limitations \\ Future Directions \\ Summary
}

\begin{abstract}
Traumatic brain injury is a problem that affects millions of Americans yearly and for which there is no definitive treatment that improves outcome. Continuous brain tissue oxygen $\left(\mathbf{P}_{b^{\prime} O_{2}}\right)$ monitoring is a complement to traditional brain monitoring techniques, such as intracranial pressure and cerebral perfusion pressure. $\mathrm{P}_{\mathrm{btO}}$ monitoring has not yet become a clinical standard of care, due to several unresolved questions. In this review, we discuss the rationale and technology of $\mathrm{P}_{\mathrm{btO}}$ monitoring. We review the literature, both historic and current, and show that continuous $\mathbf{P}_{\mathrm{btO}_{2}}$ monitoring is feasible and useful in patient management. $\mathrm{P}_{\mathrm{btO}_{2}}$ numbers reflect cerebral blood flow and oxygen diffusion. Thus, continuous monitoring of $\mathrm{P}_{\mathrm{btO}}$ yields important information about both the brain and the lung. The preclinical and clinical studies demonstrating these findings are discussed. In this review, we demonstrate that patient management in a $\mathbf{P}_{\mathrm{btO}_{2}}$-directed fashion is not the sole answer to the problem of treating traumatic brain injury but is an important adjunct to the armamentarium of multimodal neuromonitoring. Key words: Licox; neurovent; cerebral pressure autoregulation; cerebral blood flow; oxygen reactivity; traumatic brain injury; brain tissue oxygenation. [Respir Care 2016;61(9):1232-1244. (C) 2016 Daedalus Enterprises]
\end{abstract}

\section{Introduction}

Traumatic brain injury (TBI) is a physical insult to the head that results in a clinically detectable alteration in

\footnotetext{
The authors are affiliated with the Department of Neurological Surgery, University of California San Francisco, San Francisco General Hospital, and the Brain and Spinal Injury Center, University of California San Francisco, San Francisco, California 94110.
}

The authors have disclosed no conflicts of interest. cognitive processing that affects $>2.5$ million people per year in the United States and an estimated 10 million people worldwide. ${ }^{1-4}$ The cognitive dysfunction that results from TBI exists along a continuum with a subtle

Correspondence: Geoffrey T Manley MD PhD, University of California, San Francisco, 1001 Potrero Avenue, Building 1, Room 101, San Francisco, CA 94110. E-mail: manleyg@ucsf.edu.

DOI: $10.4187 /$ respcare. 04962 
alteration in sensorium on the mild end and frank coma on the severe end. Despite decades of research into the pathophysiology of TBI, there is currently no reliable treatment option for TBI or its cognitive and psychological sequelae.

The underlying assumption of TBI research is that brain injury causes a pathological change in cerebral physiology that directly leads to a cascade of secondary injury. This secondary injury culminates in neuronal death, which can yield widespread symptoms, including cognitive dysfunction. Preventing secondary injury and neuronal death is challenging because TBI has been shown to cause a derangement in a wide range of neurophysiological parameters. It is the investigators' task to determine which of these parameters correlates most closely with the fundamental pathophysiology and can be used to monitor the extent of disease and the response of the brain to treatment.

Limitations to treating TBI are related to the information that can be gathered about the injured brain. Here, we review literature suggesting that one of the fundamental pathophysiological changes that occurs after TBI is a derangement of oxygen delivery to neural tissue. Practically, this postulate suggests that brain tissue oxygenation $\left(\mathrm{P}_{\mathrm{btO}_{2}}\right)$ should be monitored in severe cases of TBI and that maintaining a normal or elevated $\mathrm{P}_{\mathrm{btO}_{2}}$ should improve outcomes after brain trauma. In this review, we first discuss the historical link between brain oxygenation and TBI. Then we focus on the different methods of measuring brain oxygenation. We then describe the ability of continuous brain tissue oxygenation monitoring to yield information about the cerebral autoregulation status of the patient. We explain the relationship between $\mathrm{P}_{\mathrm{btO}_{2}}$ and lung function. Finally, we focus on the limitations of measuring brain tissue oxygenation and future directions in the field of multimodal monitoring for traumatic brain injury.

\section{Why Monitor Brain Tissue Oxygen After Injury?}

Operating under the assumption that alterations in brain physiology directly cause the dysfunctions that define TBI, it is important to monitor physiological parameters that correlate with disease severity. Indeed, enhanced monitoring is a hallmark of modern ICU care and has been shown to correlate with positive outcomes. ${ }^{5}$ Historically, pupil diameter, corneal reflexes, and other aspects of the neurological exam have been the key variables used by clinicians to monitor disease progression in TBI. These variables are deduced from the physical exam and are analogous to auscultating the heart and lungs during cardiopulmonary failure. The neurological examination remains the mainstay of ICU monitoring for patients with brain injury. Unlike the progress that has been made in cardiovascular and respiratory monitoring, in which multiple data points are available to help guide treatment, streamlined multimodal monitoring protocols for the brain are absent.

Outside of the neurological examination, the most common physiological parameter monitored in TBI is intracranial pressure (ICP). ICP is conceptualized by the Monro-Kellie doctrine, which states that intracranial pressure is a function of the amount of brain tissue, blood, and cerebrospinal fluid present within the skull. ${ }^{6}$ From this general doctrine, ICP can be used to estimate the cerebral perfusion pressure and, hence, the amount of oxygen that is reaching the brain per unit of time. However, despite representing a major step forward in monitoring, ICP does not represent a complete picture of pathophysiology during TBI. Cerebral oxygenation, cerebral metabolism, cerebral blood flow, and autoregulation status are all useful adjuncts to the management of the brain-injured patient. ICP monitoring alone does not track the underlying pathophysiological processes that govern the degree of injury and potential for recovery after brain injury.

A key physiological variable in TBI is brain oxygenation. Exemplifying the tight relationship between brain injury and brain oxygenation, very early papers often categorized anoxic brain injury and TBI together as a single disease, given their similarities in clinical presentation. ${ }^{7}$ The importance of oxygen in TBI was only strengthened in the decades that followed, ${ }^{8-11}$ culminating in the seminal work by Chesnut et al, 12 in which avoidance of secondary injury, primarily by maintaining oxygenation and blood pressure in the early stages after brain injury, correlated with positive outcomes. Thus, the amount of oxygen that the brain tissue receives is a fundamental physiological process that is disrupted by TBI. Monitors that directly measure this cerebral physiology should, in theory, track disease severity and serve as determinants as to when more invasive treatments are needed. In this context, ICP and cerebral perfusion pressure alone, although important monitoring variables, may not predict outcome because they are only indirect metrics of the physiological processes underlying TBI.

\section{How Should Brain Tissue Oxygen Be Measured?}

The argument in favor of measuring brain oxygenation is simple: By closely following and maintaining cerebral oxygenation, it may be possible to minimize the impact of secondary injury. However, it is not clear how brain oxygenation should be measured. Early studies measured the degree of hypoxia in the brain after injury by analyzing autopsy studies of brain-injured patients. They noted that areas of local and global ischemia that occurred after TBI correlated with disease severity and also that certain areas of the brain (eg, hippocampus) were disproportionately affected after injury. ${ }^{13,14}$ These studies showed that brain ischemia and TBI are inextricably linked, bolstering the 
view that brain oxygenation is the primary pathophysiological change in TBI.

After postmortem studies demonstrated that brain oxygen was a key cause of mortality, subsequent research focused on methods to measure oxygenation during the acute phase of the illness and increasing oxygen in the brain as much as possible. The first studies implemented peripheral oxygen saturation measurements as a proxy for brain tissue oxygen and mean arterial pressure for cerebral perfusion pressure. ${ }^{11,12,15}$ These studies were a landmark in the field of TBI and demonstrated that even moderate periods of hypoxia and hypotension were sufficient to cause a large increase in mortality after TBI. However, there are a number of problems with using peripheral physiological markers to monitor disease severity in TBI. First, because of cerebral autoregulation that maintains cerebral blood flow for varying degrees of ICP and mean arterial pressure, it is simply not possible to know the cerebral perfusion pressure without knowing the ICP. Second, hypoxia that is measured peripherally is affected by a number of factors outside of the brain, including the oxygen extraction by peripheral tissue. Thus, peripheral oxygen is a very coarse measure of brain oxygenation.

To overcome these issues, there needs to be a direct method of measuring brain oxygenation. Measuring cerebral blood flow is a strategy to obtain comparable information about the brain. This can be done directly using positron emission tomography ${ }^{16}$ or xenon computed tomography (CT). ${ }^{17,18}$ These methods provide accurate and useful measures of cerebral blood flow; however, these techniques only provide a snapshot in time and cannot be used to continuously monitor patients. Thus, positron emission tomography and xenon CT are imaging techniques that are largely used to measure cerebral perfusion dynamics after an ischemic stroke but have limited utility in the continuous measurement of brain oxygenation.

Another method of measuring brain oxygenation is by placing a monitor in the jugular bulb and quantifying the percentage saturation of the venous blood returning to the heart $\left(\mathrm{S}_{\mathrm{jvO}_{2}}\right) \cdot \mathrm{S}_{\mathrm{jvO}_{2}}$ is a global measure of how much oxygen is being extracted by the entire brain. $\mathrm{S}_{\mathrm{jvO}}$ desaturation, defined as a value of $<50-55 \%$ for $>10 \mathrm{~min}$, has been associated with poor neurologic outcome. ${ }^{19-21}$ Conversely, an $\mathrm{S}_{\mathrm{jvO}_{2}}$ elevated $>75 \%$ is also associated with poor outcome in patients with severe TBI. ${ }^{20}$ Due to the association between abnormal values and poor outcome, $\mathrm{S}_{\mathrm{jvO}_{2}}$ has been used as a primary outcome in clinical trials. ${ }^{22}$ However, $\mathrm{S}_{\mathrm{jvO}_{2}}$ is often subject to artifacts due to patient head position and the proximity of the probe to the jugular bulb ${ }^{2321,24,25}$ As a result, it has not been used widely in routine TBI critical care. To overcome the unreliable nature of the $\mathrm{S}_{\mathrm{jvO}_{2}}$ and to gain a better understanding of the oxygen delivery to neural tissue, electrodes were developed to directly measure the $\mathrm{P}_{\mathrm{O}_{2}}$ in brain tissue.

\section{The Technology of the Partial Pressure of Brain Oxygen}

There are 2 main methods to measure oxygen in the brain. The first is based on the Clark electrode, which is a general purpose electrode used to measure the $\mathrm{P}_{\mathrm{O}_{2}} \cdot{ }^{26}$ The Clark electrode works by opposing 2 metallic surfaces (a gold cathode and a silver anode) in an aqueous electrolyte potassium chloride solution and allowing oxygen to diffuse into the solution. The oxygen carries forth an electrochemical reaction and creates an electric potential between the 2 surfaces, thus allowing the resulting current to be measured (Fig. 1A). The greater the amount of oxygen, the greater the electric current generated and, thus, the larger the reading of the Clark electrode. This electrode is used extensively in medicine to measure oxygen partial pressure in blood ${ }^{28}$ and muscle. ${ }^{29}$ The Licox $\mathrm{P}_{\mathrm{btO}_{2}}$ monitoring system (Integra Life Sciences Corporation, Plainsboro, New Jersey) uses this same technology and applies it to neural tissue. ${ }^{30-32}$ The disadvantage of the Licox electrode is that it measures in a very focal space, thus limiting the capture of $\mathrm{P}_{\mathrm{btO}_{2}}$ information to one area. ${ }^{33}$ Another disadvantage is that the amount of oxygen diffused in the electrolyte solution is dependent on the configuration of the anode and the cathode as well as the temperature of the surrounding tissue. Thus, each Licox electrode has its own temperature-current curve, which has to be calibrated individually for each patient. The newest versions of the Licox $\mathrm{P}_{\mathrm{btO}}$ monitoring system come with a precalibrated card for each probe that allows the calibration information to be utilized without end-user calibration steps.

The second method of measuring $\mathrm{P}_{\mathrm{btO}_{2}}$ uses fluorescence technology. ${ }^{34}$ These sensors contain a light source that shines on a medium containing a light-absorbing dye. This absorption processes is hindered by oxygen (Fig. $1 \mathrm{~B}, \mathrm{C})$. With more oxygen in the medium, fewer photons are reabsorbed by the light detector and then converted into an electric current and amplified, yielding the $\mathrm{P}_{\mathrm{btO}} \mathrm{O}_{2}$.

The initial fluorescence-based probe (Neurotrend) and the electrochemical-based probe (Licox) showed differences in threshold values in published clinical studies. Studies were done to assess whether differences in probe technology and design accounted for clinical differences and to assess whether performance in vivo was accurate as compared with in vitro conditions. Comparisons of the 2 probe types showed that the Neurotrend probe had a tendency toward higher $\mathrm{P}_{\mathrm{btO}_{2}}$ values, which may have been related to differing positions of the oxygen sensor on the probe. ${ }^{35}$ The oxygen sensor on the Neurotrend probe was near the top of the probe, providing a closer proximity to gray matter after insertion. The Licox oxygen sensor, located at the tip of the probe, allows for consistent white matter measurements. Gray matter has higher $\mathrm{P}_{\mathrm{btO}}$ measurement values than white matter, which could account 


\section{Brain Tissue Oxygen Monitoring}

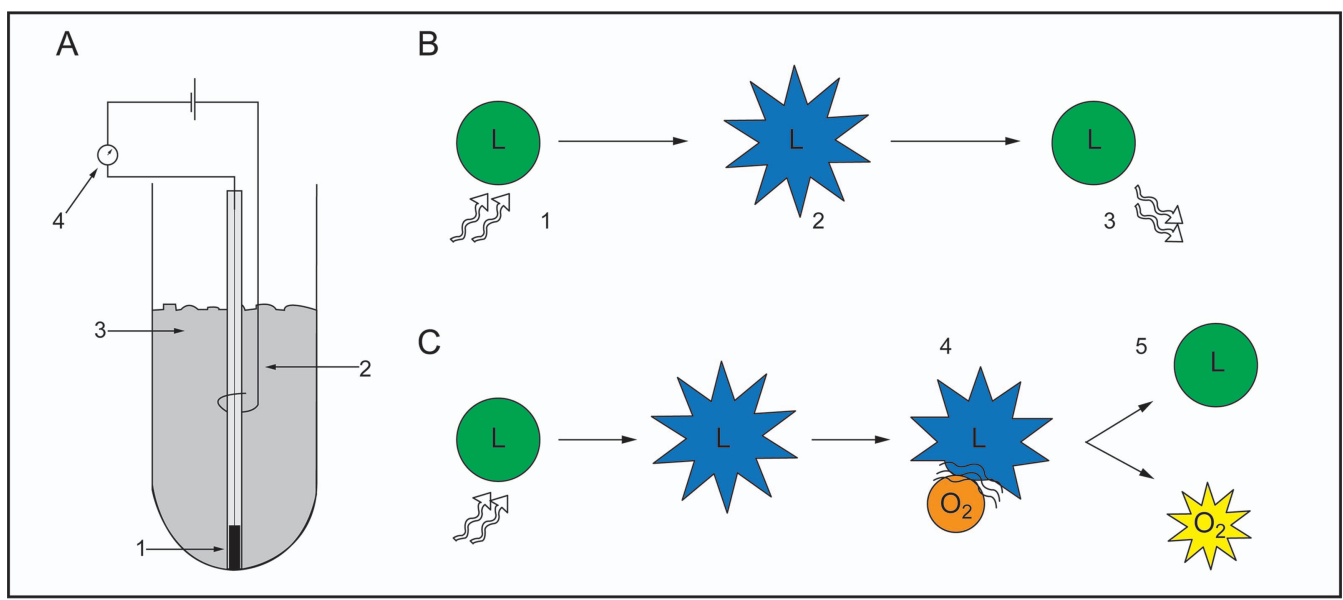

Fig. 1. The technology of brain tissue oxygen monitoring. A: Illustration demonstrating the features of Clark electrode technology, including gold cathode (1), silver anode (2), and potassium chloride solution (3). Molecular oxygen is electrolytically reduced, which creates a current that is measured by the galvanometer (4). B: Schematic showing the concept of luminescence quenching. The properties of a luminophore ( $L$ ) in the absence of oxygen are shown. Light is absorbed by the luminophore (1), which generates an excited state (2). The luminophore becomes deactivated and releases light (3), which can be measured. C: In the presence of molecular oxygen $\left(\mathrm{O}_{2}\right)$, the excited luminophore collides with oxygen (4). This causes the luminophore to be deactivated without the emission of light (5). Adapted from Reference 27.

for higher $\mathrm{P}_{\mathrm{btO}_{2}}$ values when using Neurotrend. The sensing surface area of the Neurotrend probe was relatively small, thereby providing a more focal measurement of tissue oxygen tension. The Licox has a larger sensing surface area, which serves to average a greater volume of tissue and provide more consistent and reproducible measurements. Additionally, in vitro measurements showed that Licox was accurate with a range of $2.1-6.3 \%$ error, whereas Neurotrend had a percentage error that ranged from 2.9 to $7.4 \%$, with the majority of this error seen when low oxygen tension was tested. In multiple in vitro tests, the electrochemical probe was found to be slightly more accurate, especially at low oxygen tension, which is important in distinguishing critical values in at-risk pa-

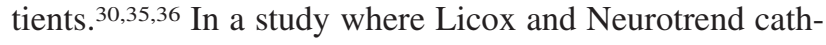
eters were placed in parallel, there was found to be a $6.25-\mathrm{mm} \mathrm{Hg}$ difference in $\mathrm{P}_{\mathrm{btO}_{2}}$ readings between the probes, which could be clinically important in cases of low $\mathrm{P}_{\mathrm{btO}_{2}} \cdot{ }^{37} \mathrm{In}$ addition, catheter malfunction was reported more frequently with the Neurotrend probe. ${ }^{37}$

Due to these findings, the Licox probe became the standard in the field. The Neurotrend went out of production in 2004. However, there are known limitations to using the Licox probe clinically. $\mathrm{P}_{\mathrm{btO}_{2}}$ measurements can take up to $2 \mathrm{~h}$ to equilibrate in vivo. In vitro studies show that in conditions of $6 \%$ oxygen at $37^{\circ} \mathrm{C}$, the Licox probe gives an accurate reading in $<100 \mathrm{~s}$. When used clinically, the probe first reads a $\mathrm{P}_{\mathrm{O}_{2}}$ consistent with atmospheric oxygen. Once the probe is inserted in the brain parenchyma, it slowly corrects to an accurate reading; however, this adaptation time averages $79 \mathrm{~min}$ (range $20-150 \mathrm{~min}$ ). For practical use, this means that $\geq 1 \mathrm{~h}$ should pass before using any readings of the probe to assess the clinical sit- uation. ${ }^{38}$ As mentioned above, positioning of the catheter in the white matter is optimal; however, malpositioning of the probe in an area of focal ischemia or hematoma can give misleading results. ${ }^{39}$ Thus, confirmation of probe placement by CT scan is standard.

Recently, a newer technology has emerged that utilizes the fiberoptic luminescence quenching properties to measure $\mathrm{P}_{\mathrm{btO}_{2}}$ and simultaneously measures ICP and temperature (Neurovent-PTO, Raumedic, Mills River, North Carolina). This technology has been compared with Licox and shows results similar to the defunct Neurotrend probes. Again, with the Neurovent-PTO, higher $\mathrm{P}_{\mathrm{btO}_{2}}$ values were noted, especially when testing in high $\mathrm{P}_{\mathrm{aO}}$ situations. ${ }^{27,40,41}$ Differences between the probes exist and have been partially attributed to the different sampling sizes of the probes. ${ }^{40,41}$ The Licox has a sampling size of $13 \mathrm{~mm}^{2}$, whereas the Neurovent-PTO samples $22 \mathrm{~mm}^{2}$ of the surrounding brain tissue. In vitro comparisons of these probes have demonstrated that, although both are accurate, Licox values more closely approximate the reference value when examining lower $\mathrm{P}_{\mathrm{btO}_{2}}$, 2 and Neurovent-PTO has a shorter response time and higher response to oxygen challenge. ${ }^{42,43}$ No probe has been demonstrated as superior, and both produce results within a clinical margin of era. To date, the majority of clinical studies and multi-center clinical trials have utilized the Clark electrode technology in the Licox probe.

\section{Validation of Cerebral Oxygen Monitoring}

With the technical challenge of measuring $\mathrm{P}_{\mathrm{btO}}$ overcome, there remained the need to validate cerebral oxygen 
monitoring and show its clinical applicability. Clinically feasible continuous brain tissue oxygen monitoring should be safe and detect changes in $\mathrm{P}_{\mathrm{btO}_{2}}$ in the setting of dynamic physiological parameters. Many preclinical studies were done in animal models before the routine clinical use of the technology. A study in the rat brain showed that contusion in the vicinity of the probe lowered the $\mathrm{P}_{\mathrm{btO}_{2}}$ reading. In that study, van den Brink et al ${ }^{39}$ also demonstrated that a small zone of edema was present histologically in the region surrounding the probe, yet overall tissue damage related to the probe was minimal. In a series of normal cats, Zauner et al ${ }^{44}$ demonstrated a mean $\mathrm{P}_{\mathrm{btO}_{2}}$ of $42 \mathrm{~mm} \mathrm{Hg}$, which decreased by $29 \%$ with hyperventilation. Manley et $\mathrm{al}^{45}$ showed that changes in brain tissue oxygen coincided with the physiological shifts that occur during hemorrhagic shock. Using a swine model, they demonstrated that a decrease in $\mathrm{P}_{\mathrm{btO}_{2}}$ was seen with hemorrhage and recovered with resuscitation. Changes in ventilation provided an increase in $\mathrm{P}_{\mathrm{btO}_{2}}$ in the setting of hypoventilation and a decrease in $\mathrm{P}_{\mathrm{btO}_{2}}$ with hyperventilation. ${ }^{45}$ Hyperventilation exacerbated the decrease in $\mathrm{P}_{\mathrm{btO}}$ during experimental hemorrhagic shock. ${ }^{46}$ These studies, while showing the feasibility of $\mathrm{P}_{\mathrm{btO}_{2}}$ monitoring, also demonstrated the ill effects of hyperventilation, which had been used as a standard treatment for patients with increased intracranial pressure. Thus, $\mathrm{P}_{\mathrm{btO}_{2}}$ monitoring began to show promise as an adjunct to current monitoring techniques in the setting of traumatic brain injury.

Early studies in patients focused on the clinical applicability of the $\mathrm{P}_{\mathrm{btO}}$ technology. Because hypoxia after severe brain injury is a significant contributor to cell death, a threshold value that could guide patient treatment was sought. van Santbrink et al ${ }^{47}$ demonstrated in brain-injured subjects that having low brain tissue oxygen, as measured by the Licox probe, was correlated with an increased risk of death. This study was followed by a larger study involving 101 subjects that demonstrated that $\mathrm{P}_{\mathrm{btO}}$ levels of $<15,10$, and $5 \mathrm{~mm} \mathrm{Hg}$ were all associated with increased risk of death or bad outcome..$^{48}$ Valadka et al ${ }^{30}$ showed that prolonged $\mathrm{P}_{\mathrm{btO}_{2}}$ of $<6 \mathrm{~mm} \mathrm{Hg}$ was not compatible with life and that $\mathrm{P}_{\mathrm{btO}_{2}}<15 \mathrm{~mm} \mathrm{Hg}$ for $>30$ min was associated with increased mortality.

\section{Hyperventilation and Carbon Dioxide Reactivity}

Early benefits of using continuous $\mathrm{P}_{\mathrm{btO}_{2}}$ monitoring included discerning the relationship between hyperventilation and brain tissue oxygen. Hyperventilation induces hypocapnia, and $\mathrm{P}_{\mathrm{aCO}_{2}}$ is a potent cerebral vasomodulator. The arterial response to $\mathrm{CO}_{2}$ results in cerebral vasodilation during episodes of hypercapnia and vasoconstriction with hypocapnia. ${ }^{49}$ The vasoconstriction that occurs with hypocapnic hyperventilation subsequently decreases cerebral blood flow and cerebral blood volume. ${ }^{50-52}$ This was historically touted as a treatment for elevated ICP because of the direct correlation between ICP and cerebral blood flow/cerebral blood volume. A decrease in cerebral blood flow, as seen with hyperventilation, leads to a decrease in ICP. Despite the benefits of decreased ICP, the negative effect of hyperventilation has been demonstrated in a variety of settings. A randomized controlled trial compared the management of subjects with severe TBI using hyperventilation as a treatment modality. This trial showed worsening outcomes in the hyperventilation group at 3 and 6 months; however, the mechanism underlying the poor performance in the hyperventilation group was unexplained. ${ }^{53}$

Studies that examined cerebral blood flow by either xenon $\mathrm{CT}^{54}$ or positron emission tomography ${ }^{55}$ demonstrated a decrease in cerebral blood flow below ischemic thresholds with hyperventilation therapy. Eighty-four percent of subjects given a hyperventilation challenge demonstrated a substantial decline in $\mathrm{P}_{\mathrm{btO}}$ even when the overall reduction in $\mathrm{P}_{\mathrm{aCO}}$ was by only $2 \mathrm{~mm} \mathrm{Hg} .{ }^{56}$ This suggested that decrements in cerebral blood flow might lead to changes in $\mathrm{P}_{\mathrm{btO}_{2}}$, which may underlie the ill effects of hyperventilation therapy.

Severely brain-injured patients often have spontaneous episodes of hyperventilation when managed on ventilator settings allowing spontaneous breaths. In these instances of hypocapnic hyperventilation, Carrera et $\mathrm{al}^{57}$ demonstrated that the decrease in $\mathrm{P}_{\mathrm{aCO}_{2}}$ still correlates with a decrease in $\mathrm{P}_{\mathrm{btO}}$. This emphasizes that the $\mathrm{P}_{\mathrm{btO}}$ response to decreased $\mathrm{P}_{\mathrm{aCO}_{2}}$ is not a function of the artificial nature of hyperventilation therapy. Attempts to modulate hyperventilation therapy by targeting $\mathrm{S}_{\mathrm{jvO}_{2}}$ revealed that maintaining a normal $\mathrm{S}_{\mathrm{jvO}_{2}}$ did not protect the $\mathrm{P}_{\mathrm{btO}_{2}}{ }^{23}$ This study, along with others, ${ }^{58}$ demonstrated that global measurements of brain oxygenation, such as with $\mathrm{S}_{\mathrm{jvO}}$, gives information complementary, but not identical, to that from regional $\mathrm{P}_{\mathrm{btO}_{2}}$ measurements. It was also further confirmed that moderate hyperventilation decreases cerebral blood flow to a level that causes a decline in regional brain tissue oxygenation.

\section{Brain Tissue Oxygen and Cerebral Pressure Autoregulation}

Research suggested a positive correlation between cerebral blood flow and $\mathrm{P}_{\mathrm{btO}_{2}} \cdot{ }^{59-61}$ This led to the question of whether continuous $\mathrm{P}_{\mathrm{btO}_{2}}$ monitoring could serve as a surrogate for cerebral blood flow and hence deliver information about the cerebral autoregulation status of the patient. Knowledge of the cerebral autoregulation status of a patient with a severe head injury can help to guide treatment and determine outcomes. Cerebral pressure autoregulation is based on the notion that cerebral vessels respond to changes in blood pressure by dilation and constriction as 

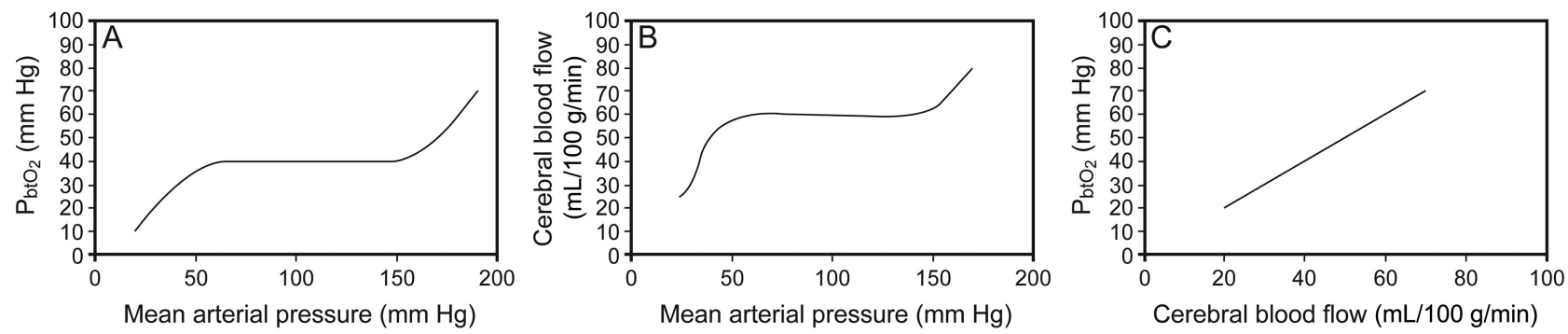

Fig. 2. Cerebral autoregulation and the relationship between cerebral blood flow and brain tissue oxygen $\left(P_{b_{t o}}\right)$. $A: P_{b t O_{2}}$ remains stable over a range of mean $\mathrm{P}_{\mathrm{aO}_{2}}$ from approximately 50 to $150 \mathrm{~mm} \mathrm{Hg}$. B: Along this same range of mean $\mathrm{P}_{\mathrm{aO}_{2}}$ values, cerebral blood flow also remains stable in a subject that shows appropriate cerebral autoregulation. C: Schematic demonstrating that $\mathrm{P}_{\mathrm{btO}_{2}}$ and cerebral blood flow are linearly related.

appropriate, similar to the $\mathrm{CO}_{2}$ reactivity explained above. This locally mediated change in vessel caliber allows cerebral blood flow to be maintained over a wide range of mean arterial pressures before the system can no longer compensate. ${ }^{62,63}$ In brain-injured patients, there is often a loss of cerebral autoregulation allowing cerebral blood flow decreases in the face of decreasing blood pressure. ${ }^{64}$

Studies of $\mathrm{P}_{\mathrm{btO}_{2}}$ showed trends in physiological factors suggesting that $\mathrm{P}_{\mathrm{btO}}$ provides information about cerebral blood flow. However, the majority of studies evaluating brain tissue oxygen were performed in experimental injury models or subjects with severe head injury; hence, the results determining the influence of normal cerebral physiology on $\mathrm{P}_{\mathrm{btO}_{2}}$ were indeterminate. A study in uninjured swine evaluated normal cerebral physiology by monitoring $\mathrm{P}_{\mathrm{btO}_{2}}$ in the setting of various challenges. In this study, it was confirmed that $\mathrm{P}_{\mathrm{btO}}$ increased linearly with increased end-tidal $\mathrm{CO}_{2}\left(\mathrm{P}_{\mathrm{ETCO}_{2}}\right)$ yet remained constant over a wide range of mean arterial pressures. ${ }^{60}$ In another study, comparisons between uninjured animals and subjects with severe TBI demonstrated that uninjured animals showed evidence of autoregulation, whereas injured subjects showed tight linear correlations between cerebral perfusion pressure and $\mathrm{P}_{\mathrm{btO}_{2}} \cdot{ }^{65}$ Direct comparisons of cerebral blood flow and $\mathrm{P}_{\mathrm{btO}}$ confirmed a tight linear correlation. Using xenon CT, a correlation between $\mathrm{P}_{\mathrm{btO}_{2}}$ and both regional and global cerebral blood flow was demonstrated in injured patients. ${ }^{59,61}$ Later, Jaeger et al ${ }^{66}$ used the continuous cerebral blood flow probe (Bowman Perfusion Monitor, Hemedex, Cambridge, Massachusetts) in combination with Licox to further verify this relationship. They demonstrated a statistically significant Pearson correlation coefficient of $\geq 0.6$ between cerebral blood flow and $\mathrm{P}_{\mathrm{btO}}$ in the majority of subject intervals examined. Thus, both $\mathrm{P}_{b_{t O}}$ and cerebral blood flow are able to demonstrate cerebral autoregulation over a range of blood pressures. Figure 2 illustrates the similarities in the pressure response curves for $\mathrm{P}_{\mathrm{btO}_{2}}$ and cerebral blood flow and the correlation between the 2 physiological measures.
Changing $\mathrm{P}_{\mathrm{btO}}$ levels replicate the changes seen in cerebral blood flow with blood pressure challenges, whereby $\mathrm{P}_{\mathrm{btO}_{2}}$ and cerebral blood flow are correlated. Menzel et al ${ }^{65}$ subsequently introduced the cerebral perfusion oxygen reactivity index to follow autoregulation status. This index, which represents the percentage change in $\mathrm{P}_{\mathrm{btO}_{2}}$ divided by the percentage change in cerebral perfusion pressure, was found to be a value of $<1$ in physiologic conditions of uninjured brain. In injured brain with loss of autoregulation, the cerebral perfusion oxygen reactivity was $>1$. Lang et al ${ }^{67}$ took a similar analytic approach. They looked at the interaction between blood pressure changes and $\mathrm{P}_{b_{t} O_{2}}$ among 14 injured subjects and demonstrated that subjects with intact autoregulation demonstrated smaller changes in $\mathrm{P}_{\mathrm{btO}_{2}}$ with cerebral perfusion pressure changes. ${ }^{67}$ The standard approach to assess cerebral autoregulation is to calculate a cerebrovascular pressure reactivity index. This index evaluates the response of ICP to changes in mean arterial pressure. Jaeger et al ${ }^{68}$ used this standard measure of autoregulation and compared it with a brain tissue oxygen pressure reactivity index and found the 2 measures to be highly correlated. This measure of autoregulation appears to be robust, since a study in pigs comparing the Licox probe to the Neurovent-PTO probe demonstrated that the brain tissue oxygen pressure reactivity was measurable and consistent between the 2 probes. ${ }^{69}$

\section{Cerebral Oxygen Reactivity}

The close relationship of $\mathrm{P}_{\mathrm{btO}_{2}}$ to $\mathrm{P}_{\mathrm{aO}_{2}}$ is easily demonstrated in studies performing oxygen challenges to maintain normobaric hyperoxia. Testing the functionality of a $\mathrm{P}_{\mathrm{btO}_{2}}$ parenchymal probe is routinely done with such an oxygen challenge. In this challenge, $\mathrm{F}_{\mathrm{IO}_{2}}$ is increased to 1.0 , and a change in $\mathrm{P}_{\mathrm{btO}}$ is observed. Due to the universality of an increase in $\mathrm{F}_{\mathrm{IO}_{2}}$ leading to an increase in $\mathrm{P}_{\mathrm{btO}}$, the absence of an increase in $\mathrm{P}_{\mathrm{btO}}$ with an oxygen challenge represents a faulty or malpositioned probe.

Although normobaric hyperoxia universally causes an increase in $\mathrm{P}_{\mathrm{btO}}$, the character of the increase can vary. 
Patients with low cerebral blood flow and low $\mathrm{P}_{\mathrm{btO}}$, baseline values show a smaller increase in $\mathrm{P}_{b_{t O}}$ with hyperoxia. ${ }^{70,71}$ This varying degree of reactivity to an oxygen challenge has been defined as relative tissue oxygen reactivity. ${ }^{47,72}$ Tissue oxygen reactivity is defined as the change in $\mathrm{P}_{\mathrm{btO}_{2}}$ divided by the change in $\mathrm{P}_{\mathrm{aO}}$, divided by the baseline $\mathrm{P}_{\mathrm{btO}_{2}}$ (tissue oxygen reactivity $=\left[\Delta \mathrm{P}_{\mathrm{btO}_{2}} / \Delta \mathrm{P}_{\mathrm{aO}} \mathrm{O}_{2}\right] / \mathrm{P}_{\mathrm{btO}_{2}}$ baseline). This relative measure gives an important way to process the oxygen challenge information. For any given oxygen challenge in which the $\mathrm{F}_{\mathrm{IO}_{2}}$ is increased to 1.0, there can be a varying degree of change in $\mathrm{P}_{\mathrm{aO}_{2}}$. Some of this variability is related to the starting $\mathrm{F}_{\mathrm{IO}_{2}}$ and starting $\mathrm{P}_{\mathrm{aO}}$ at the beginning of the challenge. Additionally, the change in $\mathrm{P}_{\mathrm{btO}_{2}}$ can vary based on the starting $\mathrm{P}_{\mathrm{btO}_{2}}$. Therefore, the relative tissue oxygen reactivity gives an accurate way to compare responses across different conditions.

Initial studies using this metric demonstrated that subjects with a lower relative tissue oxygen reactivity had a better outcome..$^{47}$ This implied that an increased reactivity to an oxygen challenge represented a disturbed autoregulation for oxygen. Additional studies confirmed these results in a larger sample size and demonstrated that an increased tissue oxygen reactivity within the first $24 \mathrm{~h}$ of injury was significantly associated with a poor outcome. ${ }^{72}$ Subjects with a favorable outcome, as defined by the Glasgow Outcome Score, had a mean relative tissue oxygen reactivity of 0.61 , whereas subjects with unfavorable outcome had a mean relative tissue oxygen reactivity of 1.03 . van Santbrink et al ${ }^{72}$ proceeded to illustrate 3 patterns of $\mathrm{P}_{\mathrm{btO}_{2}}$ response to hyperoxia. Type A shows a sharp increase of $\mathrm{P}_{\mathrm{btO}_{2}}$ that reaches a plateau within minutes, when $\mathrm{F}_{\mathrm{IO}_{2}}$ is increased. An $\mathrm{F}_{\mathrm{IO}_{2}}$ challenge that results in a sharp increase in $\mathrm{P}_{\mathrm{btO}_{2}}$ followed by a gradual increase that continues without a plateau within $15 \mathrm{~min}$ is labeled Type B. A Type $C$ response is a hybrid in which a sharp increase initially plateaus but then results in a second breakthrough increase in $\mathrm{P}_{\mathrm{btO}_{2}}$. It was observed that Type A and $\mathrm{B}$ patterns occurred more frequently ( 40 and $44 \%$, respectively), and there was a trend toward improved outcome in subjects showing Type A curves $(P=.06)$. Given the importance of the change in $\mathrm{P}_{\mathrm{aO}_{2}}$ to relative tissue oxygen reactivity, it is unlikely that cerebral factors affect oxygen reactivity in isolation.

\section{Brain Tissue Oxygen and Oxygen Diffusion}

The importance of $\mathrm{P}_{\mathrm{btO}_{2}}$ in relation to cerebral blood flow, $\mathrm{P}_{\mathrm{aO}}$, cerebral pressure autoregulation, $\mathrm{CO}_{2}$ reactivity, and $\mathrm{O}_{2}$ reactivity should not be overlooked. However, the assumption that low $\mathrm{P}_{\mathrm{btO}_{2}}$ also represents cerebral ischemia is simplistic and inaccurate. Ischemia, the balance between oxygen delivery and oxygen metabolism, is an elusive target. According to the Fick principle, the amount of oxygen that diffuses across the blood-brain barrier to the brain equals the cerebral blood flow times the difference in arterial and venous oxygen content. This is equivalent to the cerebral metabolic rate of oxygen plus the rate of accumulation of oxygen in the tissue. This equation can be rearranged to show that the cerebral metabolic rate of oxygen is nearly equivalent to the cerebral blood flow times the $\mathrm{O}_{2}$ off-loaded from hemoglobin plus the cerebral blood flow times the $\mathrm{O}_{2}$ dissolved in plasma (Fig. 3A). Rosenthal et al ${ }^{73}$ studied injured subjects with $\mathrm{P}_{\mathrm{btO}_{2}}$ and cerebral blood flow probes and demonstrated with multivariable analysis that $\mathrm{P}_{\mathrm{btO}_{2}}$ is most dependent on the cerebral blood flow times the difference in arterial and venous oxygen tension. This corroborates the finding that $\mathrm{P}_{\mathrm{btO}_{2}}$ is linearly related to $\mathrm{P}_{\mathrm{aO}}$ and cerebral blood flow. ${ }^{60}$ Thus, $\mathrm{P}_{\mathrm{btO}_{2}}$ monitoring is a reflection of the dissolved oxygen within the plasma that diffuses across the blood-brain barrier rather than entire oxygen content or cerebral metabolism. Thus, $\mathrm{P}_{\mathrm{btO}_{2}}$ is not an ischemia monitor, but low values can provide information about low $\mathrm{P}_{\mathrm{aO}_{2}}$ or cerebral blood flow. This also suggests that $\mathrm{P}_{\mathrm{btO}}$ is not merely a surrogate for cerebral blood flow and that factors that influence the amount of dissolved plasma oxygen (such as $\mathrm{pH}$, temperature, altitude, $\mathrm{P}_{\mathrm{aCO}_{2}}$, and allosteric effectors of hemoglobin) probably influence tissue oxygen reactivity.

\section{Brain Tissue Oxygenation and the Role of the Lung}

The strong influence of $\mathrm{P}_{\mathrm{aO}_{2}}$ on $\mathrm{P}_{\mathrm{btO}_{2}}$ suggests that factors contributing to low $\mathrm{P}_{a O_{2}}$ can affect $\mathrm{P}_{b t O_{2}}$. One such factor in a mechanically ventilated patient is an inadequate $\mathrm{F}_{\mathrm{IO}_{2}}$. Although an attractive solution to correct a low $\mathrm{P}_{\mathrm{btO}_{2}}$ in a ventilated patient is to increase the $\mathrm{F}_{\mathrm{IO}_{2}}$ and subsequently the $\mathrm{P}_{\mathrm{aO}}$, there are risks to prolonged normobaric hyperoxia. Prolonged $\mathrm{F}_{\mathrm{IO}_{2}}>0.6$ is known to cause hyperoxic acute lung injury due to the production of reactive oxygen species and the cellular damage incurred on lung tissue. ${ }^{74,75}$ In brain tissue, hyperoxia can similarly cause cellular dysfunction and exacerbate brain injury. In studies of stroke and traumatic brain injury, although evidence exists that normobaric hyperoxia may be neuroprotective, ${ }^{76-79}$ there is counterevidence that hyperoxia does not improve outcome and is detrimental. ${ }^{77,79-82}$ Prolonged hyperoxia may provide some temporary benefits, such as a decrease in cerebral edema; however, this "benefit" is probably due to a compensatory cerebral vasoconstriction, which risks a decrease in cerebral blood flow and increased ischemia in vulnerable tissue.

In addition to these risks of hyperoxia, a solely $\mathrm{F}_{\mathrm{IO}_{2}}{ }^{-}$ directed strategy to address a low $\mathrm{P}_{\mathrm{btO}_{2}}$ may be a solution for the number but not for the cause of the problem. In a study examining oxygen reactivity in the context of lung injury, divergent patterns of oxygen reactivity were seen. ${ }^{83}$ Rosenthal et al ${ }^{83}$ examined $\mathrm{P}_{\mathrm{btO}}$ responses to oxygen challenge while noting the lung function of the subject by 

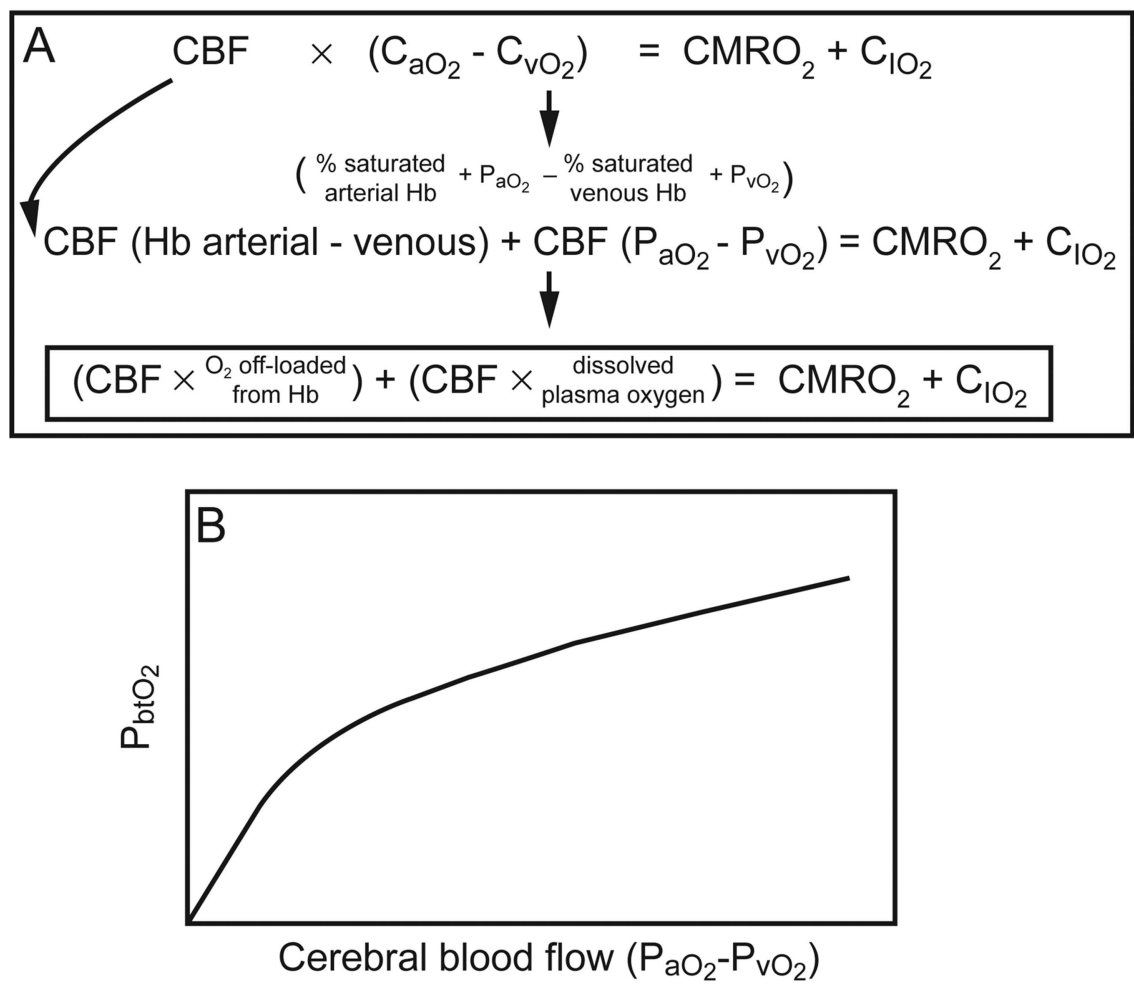

Fig. 3. A: The Fick equation of cerebral oxygen metabolism can be rearranged and represented as denoted. B: Experimental data and multivariable analysis show that the brain tissue oxygen value $\left(\mathrm{P}_{\mathrm{btO}}\right)$ is most closely related to the product of cerebral blood flow $(\mathrm{CBF})$ and the difference in dissolved plasma oxygen. $\mathrm{C}_{\mathrm{aO}_{2}}=$ arterial oxygen content; $\mathrm{C}_{\mathrm{vO}}=$ venous oxygen content; $\mathrm{CMRO}_{2}=$ cerebral metabolic rate of oxygen; $\mathrm{ClO}_{2}=$ rate of accumulation of oxygen in the tissue. Data from Reference 73 .

assessing the $\mathrm{P}_{\mathrm{aO}_{2}} / \mathrm{F}_{\mathrm{IO}_{2}}$. Using the criterion that $\mathrm{P}_{\mathrm{aO}} / \mathrm{F}_{\mathrm{IO}_{2}}$ $<250 \mathrm{~mm} \mathrm{Hg}$ represents poor lung function (atelectasis, pneumonia, lung injury), responses to hyperoxia were compared in subjects with $\mathrm{P}_{\mathrm{aO}_{2}} / \mathrm{F}_{\mathrm{IO}_{2}}>250 \mathrm{~mm} \mathrm{Hg}$ versus $\mathrm{P}_{\mathrm{aO}_{2}} / \mathrm{F}_{\mathrm{IO}_{2}}<250 \mathrm{~mm} \mathrm{Hg}$. As expected, both groups showed consistent correlations of increased $\mathrm{P}_{\mathrm{btO}}$ with increased $\mathrm{P}_{\mathrm{aO}}$. However, the pattern of increase differed. Braininjured subjects with normal lung function showed a sharp increase in $\mathrm{P}_{\mathrm{btO}_{2}}$ that reached a plateau quickly, similar to van Santbrink Type A oxygen reactivity (Fig. 4A). Subjects with lung injury showed a slower response to $\mathrm{P}_{\mathrm{aO}_{2}}$ increase that did not plateau immediately, as is seen in van Santbrink Type B (Fig. 4B). Rosenthal et $\mathrm{al}^{73}$ did not find a relationship between tissue oxygen reactivity and outcomes, possibly due to sample size. However, when the tissue oxygen reactivity is calculated based on the published data, tissue oxygen reactivity is lower in an example with $\mathrm{P}_{\mathrm{aO}_{2}} / \mathrm{F}_{\mathrm{IO}_{2}}>250 \mathrm{~mm} \mathrm{Hg}$ and higher in an example with $\mathrm{P}_{\mathrm{aO}_{2}} / \mathrm{F}_{\mathrm{IO}_{2}}<250 \mathrm{~mm} \mathrm{Hg}$. Thus, oxygen reactivity detected during an oxygen challenge may indicate as much about the injury status of the lung as it does the brain.

Decreased $\mathrm{P}_{\mathrm{btO}_{2}}$ can be a signal of poor pulmonary gas exchange. Because $\mathrm{P}_{b_{t O}}$ is so closely linked to $\mathrm{P}_{a \mathrm{O}}$, changes in $\mathrm{F}_{\mathrm{IO}_{2}}$ are directly reflected in changes in $\mathrm{P}_{\mathrm{btO}}$. In fact, the opposite is also true, in that a spontaneous decrease in
$\mathrm{P}_{\mathrm{btO}_{2}}$ can often represent poor pulmonary oxygenation and a low $\mathrm{P}_{\mathrm{aO}}$. In $\mathrm{P}_{\mathrm{btO}_{2}}$-mediated treatment, the first step in treating a low $\mathrm{P}_{\mathrm{btO}}$ involves verifying that $\mathrm{P}_{\mathrm{aO}}$ is $\geq 100 \mathrm{~mm} \mathrm{Hg}$. Changes in lung function, such as atelectasis, a new pneumonia, or developing ARDS, will cause a decrease in $\mathrm{P}_{\mathrm{aO}}$ to $<100 \mathrm{~mm} \mathrm{Hg}$, which is often first detected by a drop in continuous $\mathrm{P}_{\mathrm{btO}_{2}}$ measurements.

\section{Lung-Protective Strategies and Brain Tissue Oxygen}

Because the injury status of the lung influences the $\mathrm{P}_{\mathrm{btO}_{2}}$ response, preventing lung injury may be an important adjuvant to brain injury treatment. However, there has been hesitancy to adopt the accepted lung-protective strategies in traumatic brain injury. ARDS is frequently seen in the setting of trauma; patients with concomitant ARDS and TBI are not uncommon. Additionally, the need for mechanical ventilation, as is universally the case in patients with severe TBI, increases the risk for ventilator-induced lung injury. The ARDS Network protocol (ARDSNet) has become the standard of care for preventing and treating ARDS. This protocol involves a lower tidal volume $(6 \mathrm{~mL} / \mathrm{kg})$ and higher PEEP. This protocol has been shown to reduce mortality in a large multi-center randomized controlled trial. ${ }^{84}$ However, in this trial and in other related 

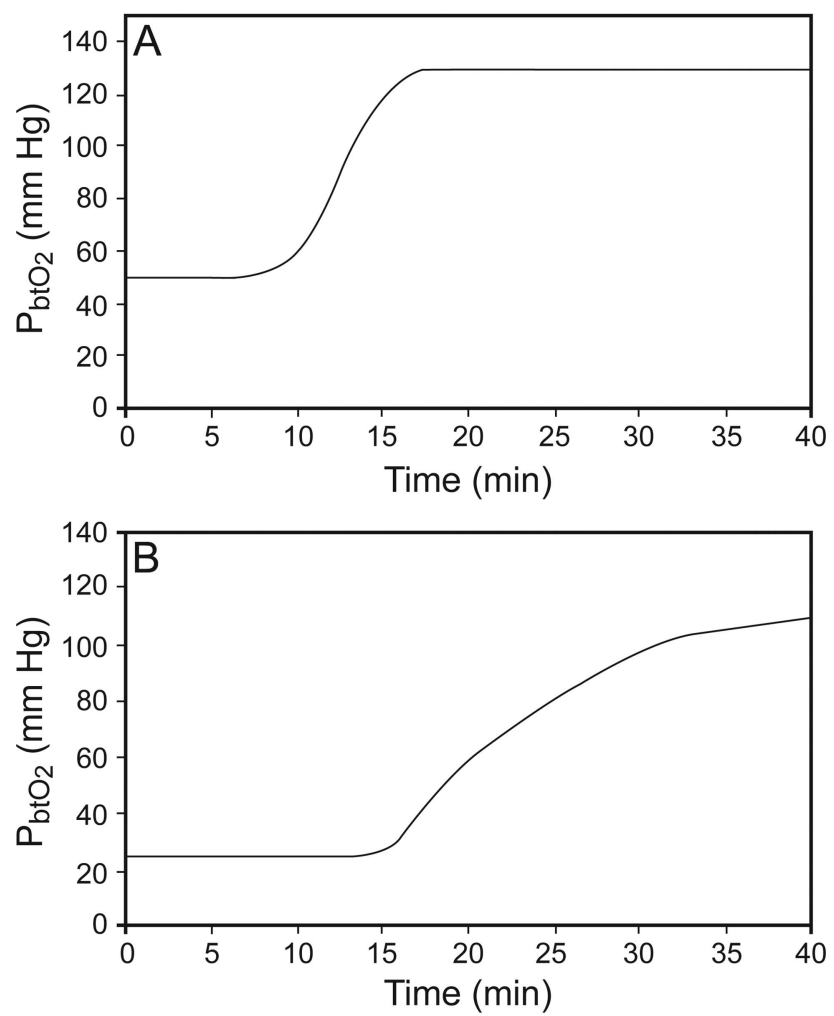

Fig. 4. Effect of lung function on brain tissue oxygen in the presence of good lung function $\left(\mathrm{P}_{\mathrm{aO}_{2}} / \mathrm{F}_{\mathrm{IO}_{2}}>250\right)$. The brain tissue oxygen $\left(\mathrm{P}_{\mathrm{btO}}\right)$ increases sharply and plateaus in the presence of an oxygen challenge $(A)$. In the setting of lung injury $\left(\mathrm{P}_{\mathrm{aO}_{2}} / \mathrm{F}_{\mathrm{IO}_{2}}<250\right)$ the response to hyperoxia is an increase in $\mathrm{P}_{\mathrm{btO}}$ that is slow and of lower amplitude (B). Data from Reference 73.

trials exploring lung-protective strategies, patients with brain injury have been excluded. The exclusion of patients with brain injury is due to the concern that an increased PEEP will increase ICP. A few studies have looked at this in animal and the results suggest that an increased PEEP can be safely administered as long as the PEEP does not exceed the ICP. ${ }^{85-87}$

However, the interaction between lung-protective strategies and brain tissue oxygen has not been thoroughly explored. As the above-mentioned paper by Rosenthal et al ${ }^{83}$ suggests, poor lung function is bad for brain tissue oxygen. This has been demonstrated by another group that examined 78 subjects with severe TBI and found a correlation between $\mathrm{P}_{\mathrm{aO}_{2}} / \mathrm{F}_{\mathrm{IO}_{2}}$ and $\mathrm{P}_{\mathrm{btO}_{2}}{ }^{88}$ Oddo et al ${ }^{88}$ showed that poor $\mathrm{P}_{\mathrm{OO}_{2}} / \mathrm{F}_{\mathrm{IO}_{2}}$ was an independent risk factor for poor $\mathrm{P}_{\mathrm{btO}_{2}}$, thus concluding, along with Rosenthal et al, ${ }^{83}$ that a lung-protective strategy is good for the brain.

Animal studies have demonstrated that a low tidal volume lung-protective strategy can be safe and improve $\mathrm{P}_{\mathrm{btO}_{2}}$. Bickenbach et al ${ }^{89}$ showed in a pig model of experimental ARDS that animals treated with low tidal volume ventilation (as compared with high volume) had higher $\mathrm{P}_{\mathrm{btO}_{2}}$ and lower cerebral lactate levels. In a swine model of combined ARDS and TBI, Davies et al ${ }^{90}$ compared ARDSNet protocol with airway pressure release ventilation. Although $\mathrm{P}_{\mathrm{btO}_{2}}$ was not directly measured, the ARDSNet group showed a better improvement in $\mathrm{P}_{\mathrm{aO}_{2}} / \mathrm{F}_{\mathrm{IO}_{2}}$ and fewer markers of cerebral injury as monitored by microdialysis.

Extreme lung-protective strategies, such as prone position, are a challenge in brain-injured patients. Prone position has been demonstrated to proffer a mortality benefit in patients with severe ARDS. ${ }^{91-93}$ The limited numbers of studies that have examined the efficacy of prone position in subjects with brain injury have found that prone position causes a slight increase in ICP; however, this is eclipsed by the clear benefit of improved oxygenation. ${ }^{94-98}$ One study evaluated $\mathrm{P}_{\mathrm{btO}_{2}}$ in subjects with ARDS and concurrent subarachnoid hemorrhage and showed that prone position was well tolerated and resulted in significant increases in $\mathrm{P}_{\mathrm{btO}_{2}}{ }^{94}$ Although more studies examining the intersection of brain and lung need to be done, the available data suggest that if a ventilatory strategy results in an improved $\mathrm{P}_{\mathrm{aO}_{2}} / \mathrm{F}_{\mathrm{IO}_{2}}$ ratio, the benefits of improved $\mathrm{P}_{\mathrm{aO}_{2}}$ will be reflected in brain tissue oxygen monitoring and improved patient outcome.

\section{Limitations}

Brain tissue oxygen monitoring has become an important component of treatment in severe traumatic brain injury. However, standardized guidelines for routine implementation of $\mathrm{P}_{\mathrm{btO}}$-directed therapy do not exist. The lack of standardized treatment guidelines is primarily due to the insufficient evidence that $\mathrm{P}_{\mathrm{btO}_{2}}$-directed management improves outcomes better than ICP and cerebral perfusion pressure-directed treatment alone. In observational studies comparing historical cohorts with $\mathrm{P}_{\mathrm{btO}_{2}}$-managed subjects, data show mortality and functional outcome benefits. ${ }^{99-101}$ However, many single-center studies have not demonstrated this benefit. In a study with 93 subjects, Meixensberger et al ${ }^{102}$ compared $\mathrm{P}_{\mathrm{btO}}$-directed therapy with cerebral perfusion pressure-directed therapy and found no difference between groups. A larger study encompassing 629 subjects found no reduction in mortality rate with a $\mathrm{P}_{\mathrm{btO}_{2}}$-guided treatment and additionally found worse functional outcome and increased utilization of hospital resources, yet the group with $\mathrm{P}_{\mathrm{btO}_{2}}$ management had a higher overall injury severity at baseline than the ICP-only managed cohort. ${ }^{103}$ The trend of lack of benefit with $\mathrm{P}_{\mathrm{btO}_{2}}$ management has been seen in many trials; however, the absence of standardized protocols to manage low $\mathrm{P}_{\mathrm{btO}}$ limits the interpretation of these studies..$^{33,104}$ As has been demonstrated, there are many factors that affect $\mathrm{P}_{\mathrm{btO}_{2}}$. A lack of protocolized treatment strategy to improve $\mathrm{P}_{\mathrm{btO}_{2}}$ numbers may have played a role in the failure of trials. ${ }^{105,106}$ 
There are some technical limitations related to $\mathrm{P}_{\mathrm{btO}_{2}}$ management. Initially, the calibration of the device led to frequent errors and inconsistencies; however, the newer $\mathrm{P}_{\mathrm{btO}_{2}}$ probes and monitoring devices have obviated that problem. The positioning of the probe can give misleading results. The probe should reside in white matter and ideally not be positioned in a focus of injured brain. Although positioning of the probe in injured brain yields important information about the injured tissue, it gives limited information as to the oxygen status of the surrounding tissue that may be vulnerable yet recoverable. Placement of a $\mathrm{P}_{\mathrm{btO}_{2}}$ probe within or in close proximity of a contusion yields lower values. ${ }^{107}$ Thus, $\mathrm{P}_{\mathrm{btO}_{2}}$ is a regional measure, and translating changes from a regional probe into conclusions about the global state of the brain has its own set of limitations.

Initial studies using $\mathrm{P}_{\mathrm{btO}_{2}}$ hoped for a continuous measure of cerebral metabolism and an indication of cerebral ischemia. However, as has been demonstrated, reduced $\mathrm{P}_{\mathrm{btO}_{2}}$ indicates low $\mathrm{P}_{\mathrm{aO}_{2}}$ or low cerebral blood flow, not total oxygen content or cerebral metabolism. ${ }^{73}$ In fact, in can be argued that the most important information derived from continuous $\mathrm{P}_{\mathrm{btO}_{2}}$ data is the interface between the lung and the brain.

\section{Future Directions}

It has been recognized that continuous monitoring of $\mathrm{P}_{\mathrm{btO}_{2}}$ has the ability to influence treatment of traumatic brain injury. $\mathrm{P}_{\mathrm{btO}_{2}}$ monitoring has been shown to be feasible, and it has been demonstrated that injured patients have episodes where $\mathrm{P}_{\mathrm{btO}}$ is abnormally low, despite normal ICPs. Despite the numerous single-center trials that have been done, a large randomized controlled trial is needed to effect standardized changes in the treatment guidelines. ${ }^{32,108} \mathrm{~A}$ phase 2 randomized clinical trial of the safety and efficacy of $\mathrm{P}_{\mathrm{btO}}$ monitoring in the management of severe TBI (BOOST 2) has been completed and demonstrates that an ICP plus $\mathrm{P}_{\mathrm{btO}_{2}}$-directed treatment strategy is feasible and safe. ${ }^{109,110}$ Definitive studies are under way to demonstrate whether $\mathrm{P}_{\mathrm{btO}_{2}}$-directed therapy is superior to ICP-directed treatment and leads to better outcomes. Additionally, new technologies in the form of noninvasive infrared spectroscopy measurements of cerebral oxygenation show promise. ${ }^{111,112}$

\section{Summary}

In summary, technological advances have made continuous $\mathrm{P}_{\mathrm{btO}_{2}}$ monitoring possible, and studies incorporating $\mathrm{P}_{\mathrm{btO}_{2}}$ have demonstrated that subjects with low values do poorly. There is a tight relationship between $\mathrm{P}_{\mathrm{btO}}$, cerebral blood flow, and $\mathrm{P}_{\mathrm{aO}}$, which underscores the important interaction between the lungs and the brain. Limitations to the universal utilization of $\mathrm{P}_{\mathrm{btO}_{2}}$ technology involve the invasive nature of the monitoring and the lack of standardized guidelines. Thus, the future of $\mathrm{P}_{\mathrm{btO}_{2}}$ monitoring includes noninvasive monitoring techniques and the creation of formal $\mathrm{P}_{\mathrm{btO}_{2}}$-directed treatment recommendations.

There is no one number that can be used to treat the brain, just as no single number is used to treat the heart. Directed interventions for brain injury require a deep understanding of cerebral physiology and the tools to acquire and visualize the data. Continuous brain tissue oxygen monitoring is not the single answer to all of the problems involved with the management of patients with TBI. However, $\mathrm{P}_{\mathrm{btO}_{2}}$ monitoring adds another data point that can be utilized to facilitate treatment goals.

\section{REFERENCES}

1. Hyder AA, Wunderlich CA, Puvanachandra P, Gururaj G, Kobusingye OC. The impact of traumatic brain injuries: a global perspective. NeuroRehabilitation 2007;22(5):341-353.

2. Faul M, Xu L, Wald MM, Coronado VG. Traumatic brain injury in the United States: emergency department visits, hospitalizations, and deaths 2002-2006. Atlanta, Georgia: National Institutes of Health; 2010.

3. Roozenbeek B, Maas AI, Menon DK. Changing patterns in the epidemiology of traumatic brain injury. Nat Rev Neurol 2013;9(4): 231-236.

4. Centers for Disease Control and Prevention. The report to congress on traumatic brain injury in the United States: epidemiology and rehabilitation. Atlanta, Georgia: National Institutes of Health; 2015.

5. Saeed M, Villarroel M, Reisner AT, Clifford G, Lehman LW, Moody $\mathrm{G}$, et al. Multiparameter intelligent monitoring in intensive care II: a public-access intensive care unit database. Crit Care Med 2011; 39(5):952-960.

6. Mokri B. The Monro-Kellie hypothesis: applications in CSF volume depletion. Neurology 2001;56(12):1746-1748.

7. Maciver IN, Frew IJ, Matheson JG. The role of respiratory insufficiency in the mortality of severe head injuries. Lancet 1958; 1(7017):390-393.

8. Price DJ, Murray A. The influence of hypoxia and hypotension on recovery from head injury. Injury 1972;3(4):218-224.

9. Miller JD, Sweet RC, Narayan R, Becker DP. Early insults to the injured brain. JAMA 1978;240(5):439-442.

10. Newfield P, Pitts L, Kaktis J, Hoff J. The influence of shock on mortality after head trauma. Crit Care Med 1980;8(4):254.

11. Miller JD, Butterworth JF, Gudeman SK, Faulkner JE, Choi SC, Selhorst JB, et al. Further experience in the management of severe head-injury. J Neurosurg 1981;54(3):289-299.

12. Chesnut RM, Marshall LF, Klauber MR, Blunt BA, Baldwin N, Eisenberg HM, et al. The role of secondary brain injury in determining outcome from severe head injury. J Trauma 1993;34(2): 216-222.

13. Graham DI, Adams JH. Ischaemic brain damage in fatal head injuries. Lancet 1971;1(7693):265-266.

14. Graham DI, Adams JH, Doyle D. Ischaemic brain damage in fatal non-missile head injuries. J Neurol Sci 1978;39(2):213-234.

15. Pigula FA, Wald SL, Shackford SR, Vane DW. The effect of hypotension and hypoxia on children with severe head injuries. J Pediatr Surg 1993;28(3):310-314; discussion 315-316.

16. Hemphill JC 3rd, Smith WS, Sonne DC, Morabito D, Manley GT Relationship between brain tissue oxygen tension and CT perfu- 


\section{Brain Tissue Oxygen Monitoring}

sion: feasibility and initial results. Am J Neuroradiol 2005;26(5): 1095-1100.

17. Drayer BP, Wolfson SK, Boehnke M, Dujovny M, Rosenbaum AE, Cook EE. Physiologic changes in regional cerebral blood flow defined by xenon-enhanced CT scanning. Neuroradiology 1978;16: 220-223.

18. Gur D, Good WF, Wolfson SK Jr, Yonas H, Shabason L. In vivo mapping of local cerebral blood flow by xenon-enhanced computed tomography. Science 1982;215(4537):1267-1268.

19. Gopinath SP, Robertson CS, Contant CF, Hayes C, Feldman Z, Narayan RK, Grossman, RG. Jugular venous desaturation and outcome after head injury. J Neurol Neurosurg Psychiatry 1994;57(6): 717-723.

20. Cormio M, Valadka AB, Robertson CS. Elevated jugular venous oxygen saturation after severe head injury. J Neurosurg 1999;90(1): 9-15.

21. Oddo M, Bösel J, Participants in the International Multidisciplinary Consensus Conference on Multimodality Monitoring. Monitoring of brain and systemic oxygenation in neurocritical care patients. Neurocrit Care 2014;21(Suppl 2):S103-S120.

22. Robertson CS, Valadka AB, Hannay HJ, Contant CF, Gopinath SP, Cormio M, et al. Prevention of secondary ischemic insults after severe head injury. Crit Care Med 1999;27(10):2086-2095.

23. Imberti $\mathrm{R}$, Bellinzona $\mathrm{G}$, Langer $\mathrm{M}$. Cerebral tissue $\mathrm{PO}_{2}$ and $\mathrm{S}_{\mathrm{jvO}_{2}}$ changes during moderate hyperventilation in patients with severe traumatic brain injury. J Neurosurg 2002;96(1):97-102.

24. Jakobsen M, Enevoldsen E. Retrograde catheterization of the right internal jugular vein for serial measurements of cerebral venous oxygen content. J Cereb Blood Flow Metab 1989;9(5):717-720.

25. Howard L, Gopinath SP, Uzura M, Valadka A, Robertson CS. Evaluation of a new fiberoptic catheter for monitoring jugular venous oxygen saturation. Neurosurgery 1999;44(6):1280-1285.

26. Clark LC Jr, Lyons C. Electrode systems for continuous monitoring in cardiovascular surgery. Ann N Y Acad Sci 1962;102:29-45.

27. Huschak G, Hoell T, Hohaus C, Kern C, Minkus Y, Meisel HJ. Clinical evaluation of a new multiparameter neuromonitoring device: measurement of brain tissue oxygen, brain temperature, and intracranial pressure. J Neurosurg Anesthesiol 2009;21(2):155-160.

28. Whalen WJ, Riley J, Nair P. A microelectrode for measuring intracellular PO2. J Appl Physiol 1967;23(5):798-801.

29. Hofer SO, van der Kleij AJ, Bos KE. Tissue oxygenation measurement: a directly applied clark-type electrode in muscle tissue. Adv Exp Med Biol 1992;317:779-784.

30. Valadka AB, Gopinath SP, Contant CF, Uzura M, Robertson CS. Relationship of brain tissue $\mathrm{PO}_{2}$ to outcome after severe head injury. Crit Care Med 1998;26(9):1576-1581.

31. Stewart C, Haitsma I, Zador Z, Hemphill JC 3rd, Morabito D, Manley G 3rd, Rosenthal G. The new Licox combined brain tissue oxygen and brain temperature monitor: assessment of in vitro accuracy and clinical experience in severe traumatic brain injury. Neurosurgery 2008;63(6):1159-1164; discussion 1164-1155.

32. Martini RP, Deem S, Treggiari MM. Targeting brain tissue oxygenation in traumatic brain injury. Respir Care 2013;58(1):162172.

33. Green JA, Pellegrini DC, Vanderkolk WE, Figueroa BE, Eriksson EA. Goal directed brain tissue oxygen monitoring versus conventional management in traumatic brain injury: an analysis of in hospital recovery. Neurocrit Care 2013;18(1):20-25.

34. Gupta AK, Hutchinson PJ, Fryer T, Al-Rawi PG, Parry DA, Minhas PS, et al. Measurement of brain tissue oxygenation performed using positron emission tomography scanning to validate a novel monitoring method. J Neurosurg 2002;96(2):263-268.
35. Haitsma I, Rosenthal G, Morabito D, Rollins M, Maas AI, Manley GT. In vitro comparison of two generations of Licox and Neurotrend catheters. Acta Neurochir Suppl 2008;102:197-202.

36. Hoelper BM, Alessandri B, Heimann A, Behr R, Kempski O. Brain oxygen monitoring: in-vitro accuracy, long-term drift and responsetime of Licox- and Neurotrend sensors. Acta Neurochir 2005;147(7): 767-774; discussion 774 .

37. Jaeger M, Soehle M, Meixensberger J. Brain tissue oxygen $\left(\mathrm{PtiO}_{2}\right)$ : a clinical comparison of two monitoring devices. Acta Neurochir Suppl 2005;95:79-81.

38. Dings J, Meixensberger J, Jäger A, Roosen K. Clinical experience with 118 brain tissue oxygen partial pressure catheter probes. Neurosurgery 1998;43(5):1082-1095.

39. van den Brink WA, Haitsma IK, Avezaat CJ, Houtsmuller AB, Kros JM, Maas AI. Brain parenchyma/ $\mathrm{PO}_{2}$ catheter interface: a histopathological study in the rat. J Neurotrauma 1998;15(10):813824.

40. Dengl M, Jaeger M, Renner C, Meixensberger J. Comparing brain tissue oxygen measurements and derived autoregulation parameters from different probes (Licox vs. Raumedic). Acta Neurochir Suppl 2012;114:165-168.

41. Wolf S, Horn P, Frenzel C, Schürer L, Vajkoczy P, Dengler J. Comparison of a new brain tissue oxygenation probe with the established standard. Acta Neurochir Suppl 2012;114:161-164.

42. Purins K, Enblad P, Sandhagen B, Lewén A. Brain tissue oxygen monitoring: a study of in vitro accuracy and stability of NeuroventPTO and Licox sensors. Acta Neurochir 2010;152(4):681-688.

43. Morgalla MH, Haas R, Grözinger G, Thiel C, Thiel K, Schuhmann MU, Schenk M. Experimental comparison of the measurement accuracy of the Licox and Raumedic Neurovent-PTO brain tissue oxygen monitors. Acta Neurochir Suppl 2012;114:169-172.

44. Zauner A, Bullock R, Di X, Young HF. Brain oxygen, $\mathrm{CO}_{2}, \mathrm{pH}$, and temperature monitoring: Evaluation in the feline brain Neurosurgery 1995;37(6):1168-1176; discussion 1176-1167.

45. Manley GT, Pitts LH, Morabito D, Doyle CA, Gibson J, Gimbel M, et al. Brain tissue oxygenation during hemorrhagic shock, resuscitation, and alterations in ventilation. J Trauma 1999;46(2):261-267.

46. Manley GT, Hemphill JC, Morabito D, Derugin N, Erickson V, Pitts LH, Knudson MM. Cerebral oxygenation during hemorrhagic shock: perils of hyperventilation and the therapeutic potential of hypoventilation. J Trauma 2000;48(6):1025-1032; discussion 10321023.

47. van Santbrink H, Maas AI, Avezaat CJ. Continuous monitoring of partial pressure of brain tissue oxygen in patients with severe head injury. Neurosurgery 1996;38(1):21-31.

48. van den Brink WA, van Santbrink H, Steyerberg EW, Avezaat CJ, Suazo JA, Hogesteeger C, et al. Brain oxygen tension in severe head injury. Neurosurgery 2000;46(4):868-876; discussion 876-868.

49. Greenberg JH, Alavi A, Reivich M, Kuhl D, Uzzell B. Local cerebral blood volume response to carbon dioxide in man. Circ Res 1978;43(2):324-331.

50. Kety SS, Schmidt CF. The effects of altered arterial tensions of carbon dioxide and oxygen on cerebral blood flow and cerebral oxygen consumption of normal young men. J Clin Invest 1948; 27(4):484-492.

51. Raichle ME, Plum F. Hyperventilation and cerebral blood flow. Stroke 1972;3(5):566-575.

52. Obrist WD, Langfitt TW, Jaggi JL, Cruz J, Gennarelli TA. Cerebral blood flow and metabolism in comatose patients with acute head injury: relationship to intracranial hypertension. J Neurosurg 1984; 61(2):241-253.

53. Muizelaar JP, Marmarou A, Ward JD, Kontos HA, Choi SC, Becker $\mathrm{DP}$, et al. Adverse effects of prolonged hyperventilation in patients 


\section{Brain Tissue Oxygen Monitoring}

with severe head injury: a randomized clinical trial. J Neurosurg 1991;75(5):731-739.

54. Stringer WA, Hasso AN, Thompson JR, Hinshaw DB, Jordan KG. Hyperventilation-induced cerebral ischemia in patients with acute brain lesions: demonstration by xenon-enhanced CT. Am J Neuroradiol 1993;14(2):475-484.

55. Coles JP, Minhas PS, Fryer TD, Smielewski P, Aigbirihio F, Donovan T, et al. Effect of hyperventilation on cerebral blood flow in traumatic head injury: clinical relevance and monitoring correlates. Crit Care Med 2002;30(9):1950-1959.

56. Carmona Suazo JA, Maas AIR, van den Brink WA, van Santbrink $\mathrm{H}$, Steyerberg EW, Avezaat $\mathrm{CJ} . \mathrm{CO}_{2}$ reactivity and brain oxygen pressure monitoring in severe head injury. Crit Care Med 2000; 28(9):3268-3274.

57. Carrera E, Schmidt JM, Fernandez L, Kurtz P, Merkow M, Stuart $\mathrm{M}$, et al. Spontaneous hyperventilation and brain tissue hypoxia in patients with severe brain injury. J Neurol Neurosurg Psychiatry 2010;81(7):793-797.

58. Gopinath SP, Valadka AB, Uzura M, Robertson CS. Comparison of jugular venous oxygen saturation and brain tissue $\mathrm{PO}_{2}$ as monitors of cerebral ischemia after head injury. Crit Care Med 1999;27(11): 2337-2345.

59. Menzel M, Doppenberg EM, Zauner A, Soukup J, Reinert MM, Clausen T, et al. Cerebral oxygenation in patients after severe head injury: monitoring and effects of arterial hyperoxia on cerebral blood flow, metabolism and intracranial pressure. J Neurosurg Anesthesiol 1999;11(4):240-251.

60. Hemphill JC 3rd, Knudson MM, Derugin N, Morabito D, Manley GT. Carbon dioxide reactivity and pressure autoregulation of brain tissue oxygen. Neurosurgery 2001;48(2):377-383; discussion 383374.

61. Valadka AB, Hlatky R, Furuya Y, Robertson CS. Brain tissue $\mathrm{PO}_{2}$ : correlation with cerebral blood flow. Acta Neurochir Suppl 2002; 81:299-301.

62. Fog M. The relationship between the blood pressure and the tonic regulation of the pial arteries. J Neurol Psychiatry 1938;1(3):187197.

63. Rangel-Castilla L, Gasco J, Nauta HJ, Okonkwo DO, Robertson CS. Cerebral pressure autoregulation in traumatic brain injury. Neurosurg Focus 2008;25(4):E7.

64. Shapiro HM. Intracranial hypertension: therapeutic and anesthetic considerations. Anesthesiology 1975;43(4):445-471.

65. Menzel M, Soukup J, Henze D, Clausen T, Marx T, Hillman A, et al. Brain tissue oxygen monitoring for assessment of autoregulation: preliminary results suggest a new hypothesis. J Neurosurg Anesthesiol 2003;15(1):33-41.

66. Jaeger M, Soehle M, Schuhmann MU, Winkler D, Meixensberger J. Correlation of continuously monitored regional cerebral blood flow and brain tissue oxygen. Acta Neurochir 2005;147(1):51-56; discussion 56.

67. Lang EW, Czosnyka M, Mehdorn HM. Tissue oxygen reactivity and cerebral autoregulation after severe traumatic brain injury. Crit Care Med 2003;31(1):267-271.

68. Jaeger M, Schuhmann MU, Soehle M, Meixensberger J. Continuous assessment of cerebrovascular autoregulation after traumatic brain injury using brain tissue oxygen pressure reactivity. Crit Care Med 2006;34(6): 1783-1788.

69. Grözinger G, Schenk M, Thiel C, Thiel K, Morgalla MH, Schuhmann MU. Is pbro2 pressure reactivity index (ORx) dependent on the type of oxygen probe? an in vivo study. Acta Neurochir Suppl 2012;114:173-176.

70. Longhi L, Valeriani V, Rossi S, De Marchi M, Egidi M, Stocchetti $\mathrm{N}$. Effects of hyperoxia on brain tissue oxygen tension in cerebral focal lesions. Acta Neurochir Suppl 2002;81:315-317.
71. Hlatky R, Valadka AB, Gopinath SP, Robertson CS. Brain tissue oxygen tension response to induced hyperoxia reduced in hypoperfused brain. J Neurosurg 2008;108(1):53-58.

72. van Santbrink H, vd Brink WA, Steyerberg EW, Carmona Suazo JA, Avezaat CJ, Maas AI. Brain tissue oxygen response in severe traumatic brain injury. Acta Neurochir 2003;145(6):429-438; discussion 438 .

73. Rosenthal G, Hemphill JC 3rd, Sorani M, Martin C, Morabito D, Obrist WD, Manley GT. Brain tissue oxygen tension is more indicative of oxygen diffusion than oxygen delivery and metabolism in patients with traumatic brain injury. Crit Care Med 2008;36(6): 1917-1924.

74. Kuipers MT, van der Poll T, Schultz MJ, Wieland CW. Bench-tobedside review: damage-associated molecular patterns in the onset of ventilator-induced lung injury. Crit Care 2011;15(6):235.

75. Kallet RH, Matthay MA. Hyperoxic acute lung injury. Respir Care 2013;58(1):123-141.

76. Tolias CM, Reinert M, Seiler R, Gilman C, Scharf A, Bullock MR. Normobaric hyperoxia-induced improvement in cerebral metabolism and reduction in intracranial pressure in patients with severe head injury: a prospective historical cohort-matched study. J Neurosurg 2004;101(3):435-444.

77. Beynon C, Kiening KL, Orakcioglu B, Unterberg AW, Sakowitz OW. Brain tissue oxygen monitoring and hyperoxic treatment in patients with traumatic brain injury. J Neurotrauma 2012;29(12): 2109-2123.

78. Veenith TV, Carter EL, Grossac J, Newcombe VF, Outtrim JG, Nallapareddy $\mathrm{S}$, et al. Use of diffusion tensor imaging to assess the impact of normobaric hyperoxia within at-risk pericontusional tissue after traumatic brain injury. J Cereb Blood Flow Metab 2014; 34(10):1622-1627.

79. Weaver J, Liu KJ. Does normobaric hyperoxia increase oxidative stress in acute ischemic stroke? a critical review of the literature. Med Gas Res 2015;5:11.

80. Magnoni S, Ghisoni L, Locatelli M, Caimi M, Colombo A, Valeriani V, Stocchetti N. Lack of improvement in cerebral metabolism after hyperoxia in severe head injury: a microdialysis study. J Neurosurg 2003;98(5):952-958.

81. Davis DP, Meade W, Sise MJ, Kennedy F, Simon F, Tominaga G, et al. Both hypoxemia and extreme hyperoxemia may be detrimental in patients with severe traumatic brain injury. J Neurotrauma 2009;26(12):2217-2223.

82. Talley Watts L, Long JA, Manga VH, Huang S, Shen Q, Duong TQ. Normobaric oxygen worsens outcome after a moderate traumatic brain injury. J Cereb Blood Flow Metab 2015;35(7):11371144.

83. Rosenthal G, Hemphill JC, Sorani M, Martin C, Morabito D, Meeker $\mathrm{M}$, et al. The role of lung function in brain tissue oxygenation following traumatic brain injury. J Neurosurg 2008;108(1):59-65.

84. Brower RG, Matthay MA, Morris A, Schoenfeld D, Thompson BT, Wheeler A, et al. Ventilation with lower tidal volumes as compared with traditional tidal volumes for acute lung injury and the acute respiratory distress syndrome. N Engl J Med 2000;342(18):13011308.

85. Muench E, Bauhuf C, Roth H, Horn P, Phillips M, Marquetant N, et al. Effects of positive end-expiratory pressure on regional cerebral blood flow, intracranial pressure, and brain tissue oxygenation. Crit Care Med 2005;33(10):2367-2372.

86. Stevens RD, Lazaridis C, Chalela JA. The role of mechanical ventilation in acute brain injury. Neurol Clin 2008;26(2):543-563, x.

87. Young N, Rhodes JK, Mascia L, Andrews PJ. Ventilatory strategies for patients with acute brain injury. Curr Opin Crit Care 2010; 16(1):45-52. 


\section{Brain Tissue Oxygen Monitoring}

88. Oddo M, Nduom E, Frangos S, MacKenzie L, Chen I, MaloneyWilensky E, et al. Acute lung injury is an independent risk factor for brain hypoxia after severe traumatic brain injury. Neurosurgery 2010;67(2):338-344.

89. Bickenbach J, Zoremba N, Fries M, Dembinski R, Doering R, Ogawa E, et al. Low tidal volume ventilation in a porcine model of acute lung injury improves cerebral tissue oxygenation. Anesth Analg 2009;109(3):847-855.

90. Davies SW, Leonard KL, Falls RK Jr., Mageau RP, Efird JT, Hollowell JP, et al. Lung protective ventilation (ARDSNet) versus airway pressure release ventilation: ventilatory management in a combined model of acute lung and brain injury. J Trauma Acute Care Surg 2015;78(2):240-249; discussion 249-251.

91. Guérin C, Reignier J, Richard JC, Beuret P, Gacouin A, Boulain T, et al. Prone positioning in severe acute respiratory distress syndrome. N Engl J Med 2013;368(23):2159-2168.

92. Lee JM, Bae W, Lee YJ, Cho YJ. The efficacy and safety of prone positional ventilation in acute respiratory distress syndrome: updated study-level meta-analysis of 11 randomized controlled trials. Crit Care Med 2014;42(5):1252-1262.

93. Kallet RH. A comprehensive review of prone position in ARDS. Respir Care 2015;60(11):1660-1687.

94. Reinprecht A, Greher M, Wolfsberger S, Dietrich W, Illievich UM, Gruber A. Prone position in subarachnoid hemorrhage patients with acute respiratory distress syndrome: effects on cerebral tissue oxygenation and intracranial pressure. Crit Care Med 2003;31(6): 1831-1838.

95. Nekludov M, Bellander BM, Mure M. Oxygenation and cerebral perfusion pressure improved in the prone position. Acta Anaesthesiol Scand 2006;50(8):932-936.

96. Thelandersson A, Cider A, Nellgård B. Prone position in mechanically ventilated patients with reduced intracranial compliance. Acta Anaesthesiol Scand 2006;50(8):937-941.

97. Athota KP, Millar D, Branson RD, Tsuei BJ. A practical approach to the use of prone therapy in acute respiratory distress syndrome. Expert Rev Respir Med 2014;8(4):453-463.

98. Roth C, Ferbert A, Deinsberger W, Kleffmann J, Kästner S, Godau $\mathrm{J}$, et al. Does prone positioning increase intracranial pressure? a retrospective analysis of patients with acute brain injury and acute respiratory failure. Neurocrit Care 2014;21(2):186-191.

99. Stiefel MF, Spiotta A, Gracias VH, Garuffe AM, Guillamondegui $\mathrm{O}$, Maloney-Wilensky E, et al. Reduced mortality rate in patients with severe traumatic brain injury treated with brain tissue oxygen monitoring. J Neurosurg 2005;103(5):805-811.

100. Narotam PK, Morrison JF, Nathoo N. Brain tissue oxygen monitoring in traumatic brain injury and major trauma: outcome analysis of a brain tissue oxygen-directed therapy. J Neurosurg 2009;111(4): 672-682.

101. Spiotta AM, Stiefel MF, Gracias VH, Garuffe AM, Kofke WA, Maloney-Wilensky E, et al. Brain tissue oxygen-directed management and outcome in patients with severe traumatic brain injury. J Neurosurg 2010;113(3):571-580.

102. Meixensberger J, Jaeger M, Väth A, Dings J, Kunze E, Roosen K. Brain tissue oxygen guided treatment supplementing ICP/CPP therapy after traumatic brain injury. J Neurol Neurosurg Psychiatry 2003;74(6):760-764.

103. Martini RP, Deem S, Yanez ND, Chesnut RM, Weiss NS, Daniel S, et al. Management guided by brain tissue oxygen monitoring and outcome following severe traumatic brain injury. J Neurosurg 2009; 111(4):644-649.

104. McCarthy MC, Moncrief H, Sands JM, Markert RJ, Hall LC, Wenker IC, et al. Neurologic outcomes with cerebral oxygen monitoring in traumatic brain injury. Surgery 2009;146(4):585-590; discussion 590-581.

105. Bohman LE, Heuer GG, Macyszyn L, Maloney-Wilensky E, Frangos S, Le Roux PD, et al. Medical management of compromised brain oxygen in patients with severe traumatic brain injury. Neurocrit Care 2011;14(3):361-369.

106. Pascual JL, Georgoff P, Maloney-Wilensky E, Sims C, Sarani B, Stiefel MF, et al. Reduced brain tissue oxygen in traumatic brain injury: are most commonly used interventions successful? J Trauma 2011;70(3):535-546.

107. Ponce LL, Pillai S, Cruz J, Li X, Julia H, Gopinath S, Robertson CS. Position of probe determines prognostic information of brain tissue $\mathrm{PO}_{2}$ in severe traumatic brain injury. Neurosurgery 2012; 70(6):1492-1502; discussion 1502-1493.

108. Haitsma IK, Maas AI. Advanced monitoring in the intensive care unit: brain tissue oxygen tension. Curr Opin Crit Care 2002;8(2): 115-120.

109. 2014 Annual Meeting Highlights, Neurocritical Care Society. http:// www.neurocriticalcare.org/news/2014-annual-meeting-highlights. Accessed March 28, 2016.

110. Diaz-Arrastia R. Brain tissue oxygenation-what have we learned from BOOST-2? J Neurotrauma 2016;33:A-2.

111. Rosenthal G, Furmanov A, Itshayek E, Shoshan Y, Singh V. Assessment of a noninvasive cerebral oxygenation monitor in patients with severe traumatic brain injury. J Neurosurg 2014;120(4):901907.

112. Wang CC, Kuo JR, Chen YC, Chio CC, Wang JJ, Lin BS. Brain tissue oxygen evaluation by wireless near-infrared spectroscopy. J Surg Res 2016;200(2):669-675. 